\title{
Experiencing a Place: Karlovac as an Older Teenagers' Daily Environment
}

\author{
Laura Šakaja, Svjetlana Višnić
}

\begin{abstract}
Spatial planners, when creating plans to develop towns, often build into them their desires and visions, or the wishes and visions of their clients. In these processes, the interests of many groups in the local population remain neglected. Successful planning of community development presumes an understanding of place experiences and place use by different groups in the local community.

Our study dealt with the daily environment of older teenagers - a group whose practices and needs are generally neglected in urban planning processes. The complexity of the research task required mixing quantitative and qualitative methods. The research was conducted among $2^{\text {nd }}, 3^{\text {rd }}$ and $4^{\text {th }}$ formers in secondary schools in Karlovac. The questionnaire included structured and open-ended questions, about important landmarks, and frequently used, preferred and avoided places. After administering the questionnaire, we worked with two focus groups. The study investigated how teenagers perceive and value their city and express their need for better representation of young people in city decision-making.
\end{abstract}

Key words: teenagers, city perception, microgeography, Karlovac

\section{Doživljavanje mjesta: Karlovac kao dnevni okoliš starijih karlovačkih tinejdžera}

U urbano planiranje nerijetko su uključeni stručnjaci koji sadržaje prostora oblikuju prema vlastitim ili vizijama $i$ iskustvima svojih klijenata, a pritom su često zanemarene potrebe lokalne zajednice. Uspješno prostorno planiranje zahtijeva poznavanje iskustva različitih grupa u društvenoj zajednici, a pojava „,bottom up” i ,grassroots” strategija nagoviješta potrebu za ojačavanjem lokalne inicijative u procesu prostornog planiranja. Naše istraživanje koncentriralo se na starije tinejdžere, jer, uz djecu, predstavljaju posebno osjetljivu i zanemarenu društvenu skupinu. Istraživanje je provedeno među učenicima 2., 3. i 4. razreda srednjih škola u Karlovcu. Primijenjene su kvantitativne i kvalitativne metode. Upitnik je sadržavao strukturirana i otvorena pitanja o topologiji dnevnog okoliša ispitanika, omiljenim mjestima, mjestima koje izbjegavaju i promjenama koje bi u grad uveli. Rezultati upitnika su konkretizirani i testirani tokom rada s fokus grupama. Cilj istraživanja bio je otkriti kako tinejdžeri percipiraju grad u cjelini, kako vrednuju pojedine prostore grada, a rezultati su otkrili i potrebu za većom uključenosti mladih u planiranje gradskog prostora.

Ključne riječi: tinejdžeri, percepcija grada, mikrogeografija, Karlovac 


\section{INTRODUCTION}

In the course of urban planning, an inevitable question, and one of the most important ones, is "for whom". For whom are the new urban plans - imagined so as to improve living conditions in a given town or city - intended? Yet spatial planners, when creating plans to develop towns, often build into them not only their professional know-how, but also their personal and thus situated and positional knowledge about the rules of city planning and city design, and often also their desires and visions, or the wishes and visions of their clients. In these processes, the interests of many groups in the local population remain unrecognised and neglected. Today many voices advocate giving the local community an active part in city and neighbourhood planning. The development of terms such as bottom-up and grassroots urban planning (as well as projects such as "Planning for real", Wratten, 2001) reflect the need to shift power in the planning process away from experts in the government or development agencies, and towards the local community.

Behavioural and humanistic approaches in geography have a long history of studying human perceptions underlying environmental behaviour, mental maps that people have of spaces around them, and places as they are perceived and experienced by different groups of people (see for example, Kirk, 1963, Tuan, 1974, Gould and White, 1986, Saarinen, Seamon and Sell (eds), 1984, Zelinsky, 1989, Boal and Livingston (eds), 1989, Bailly, MacCabe and Saarinen, 1995, André and Bailly, 1998).

Various studies in the social sciences, while investigating the "sacred structure" (Hester, 1993), or the "territorial identity" (Roca and Roca, 2007) of a place, have developed methods for researching and preserving environments that are vital to the lifestyles of community members, and that account for important parts of a community's daily routine. It should be noted that the term place in this article is understood in accordance with Edward Relph's definitions as "fusions of physical attributes, activities and significance" (Relph, 2008, 35) or "as tightly interconnected assemblages of buildings, landscapes, communities, activities and meanings which are constituted in the diverse experiences of their inhabitants and visitors (Relph, 2002, 907-908). Environments, to which people are attached, often seem mundane, and as such are not recognised either by institutions dealing with the preservation of heritage, or by official planning mechanisms. In this paper, our postulate is that successful planning of community development presumes an understanding of place experiences and place use by different groups in the local community. Our study dealt with the daily environment of older teenagers - a group whose practices and needs are generally neglected in urban planning processes.

In the 1990's, Hugh Mathews and Melaney Limb indicated "the need to understand children from the perspective of their own multiple lifeworlds and to recognise that they may have very different values about place and space from the adults" (Matthews and Limb, 1999, 68). Using the term "children" in reference to the age span from 5 to 16 years of age, they called for a move towards a solidly grounded social and cultural geography of children and proposed an agenda for such a geography, which would "acknowledge processes of exclusion, sociospatial marginalisation and boundary conflicts with adults and parents" (ibidem, 82). They also pointed out that the voices of children and young teenagers are silent in regard to the landscape, ignored in the planning process and 
under-represented in grounded scientific research (Matthews, Limb and Percy-Smith, 1998). This appeal for a geography of children was apparently very effective, and it inspired a substantial corpus of studies carried out in the 2000's examining the place use and place behaviour of children (Horton, J., Kraftl, P. and Tucker, F., 2008). Yet in this mass of research work, only a few papers (Mäkinen and Tyrväinen, 2008; Travlou, 2004; Travlou, Owens, Thompson, Maxwell, 2008; Owens, 1994) dealt with the everyday local environments, spatial preferences and experiences of older teenagers. In our paper we will focus precisely on this age group.

Our research was conducted among $2^{\text {nd }}, 3^{\text {rd }}$ and $4^{\text {th }}$ formers in secondary schools in Karlovac: $80 \%$ of the sample were $16-17$ year-olds, $12 \%$ were 18 year-olds and $8 \% 15$ year-olds. We selected this age grouping for the following reason. The period of secondary school is a time when one starts to experience a city independently. Since secondary schools, as opposed to elementary ones, are rarely chosen mostly on the basis of location proximity, the move from elementary to secondary school marks a shift from the "spatial bubble" (Matthews and Limb, 1999, 72) of the neighbourhood towards a considerable wider area of the town. Urban space becomes a vital resource in personal development.

The study was conducted in Karlovac, a city located in the central part of Croatia. According to the last census (2001), the population of Karlovac amounted to 50,000 people.

The complexity of the research task, which involved investigating the topology of teenagers' daily environments consisting of important landmarks, and frequently used, preferred and avoided places, required mixing quantitative and qualitative methods. The research began with a pilot study, which provided valuable information for designing a case-specific questionnaire that was administered to secondary school pupils. The questionnaire included structured and open-ended questions. The representative sample consisted of 170 pupils in the age group from 15 to 18 years. Half of the sample was made up of grammar school pupils, and the other half of pupils in vocational schools - technical, medical and forestry-woodworking schools. Boys and girls were equally represented (85 in each group). After administering the questionnaire, we worked with two focus groups, one with boys and another with girls - with five persons in each group. The focus groups, as well as informal behaviour observation at selected places, helped us to confirm and develop the general findings of the survey.

The basic questions that we wished to answer were the following:

- What is the overall image of Karlovac from the perspective of young people?

- Which places in the town do young people consider as favourable and most often visit?

- Which areas in the town do they consider uncomfortable or scary?

- What are the teenagers' environmental needs and what moves (decisions/changes) do they wish city politicians would make?

\section{THE OVERALL IMAGE OF KARLOVAC}

To reconstruct the overall image of the town as seen by teenagers, we made use of various methods. First, from a total of 32 offered adjectives, the respondents were asked to 
select ten that best described Karlovac and to arrange them in the order that best described the city. In the following task, involving an open-ended question, respondents were asked to select by themselves one word that best describes Karlovac and to write their own description of the town. When we processed the answers it become obvious that respondents defined the town mostly in relation to its nature and greenery: parks, lanes and the banks of the rivers Kupa, Korana, Mrežnica and Dobra around which the town developed. Moreover, the answers also indicated that teenagers mainly experience their town as cosy, small, nice, quiet, accessible, clean, gentle and safe. Most adjectives, as we noticed, fitted into the axiological system "Heimlich / homely" (= home-like) and indicated an area that was friendly, familiar, intimate, hospitable and secure. The respondents' descriptions of Karlovac clearly revealed their pride in its heritage sites - among the most beautiful locations in the town, the Dubovac Castle was consistently mentioned - a medieval fortress on a hill not far from the centre of the town, with an attractive panorama and picturesque walkways. The strong affective feeling of the teenagers towards their everyday world was expressed by words such as beautiful, wonderful, special and home.

Undoubtedly, as in the case of every urban centre, Karlovac has it beautiful and less beautiful parts, but generally it was described positively. Nevertheless, some of the respondents saw the town as boring and monotonous and as not offering many opportunities. This group of answers contained a series of designations by which teenagers defined Karlovac as - boring, dull, a village, unutilised, without perspective, empty-poor, grey, not modern, modest, a primitive backwater. Diametrically opposed appraisals of the dimensions of the town once more proved that there is no homogeneous social category that could be labelled as "teenagers" (Matthews, Limb and Percy-Smith, 1998). Specifically, in respect to the dimensions of the town, one part of the respondents described Karlovac as a town measured to human being, or with everything at hand, whereas others experienced it as $a$ town, where you have nowhere to go out to. It is interesting to note that "boring" as one of the basic experiences of a home territory has appeared in the research findings of other authors. "Lack of things to do", as shown by these studies, is a frequent complaint made by teenagers in small and middle-sized towns (Lynch and Banerjee, 1976). Moreover, 35\% of the respondents wish to change their place of residence, the main reason being that the town does not provide them with sufficient opportunities, possibilities for amusement, and other content.

\section{FAVOURABLE PLACES}

The second basic question we addressed in our research was - which places in the town do young people consider as favourable and visit most often?

Research on the microgeography of children and teenagers usually concentrates to a great extent exactly on favourable places, locations "where they best like to be".

Studies by Lynch, Chawla, Matthews, Owens and other authors showed that children's and adolescents' favourite places are usually "unprogrammed places" (Lynch, 1977, Lynch and Banerjee, 1976, Owens, 1988, Owens, 1994, Matthews, Limb and Percy-Smith, 1998, Chawla, 2002, Schwab and Standler, 2004, Mäkinen and Tyrväinen, 2008). This was also fully confirmed by our research. 


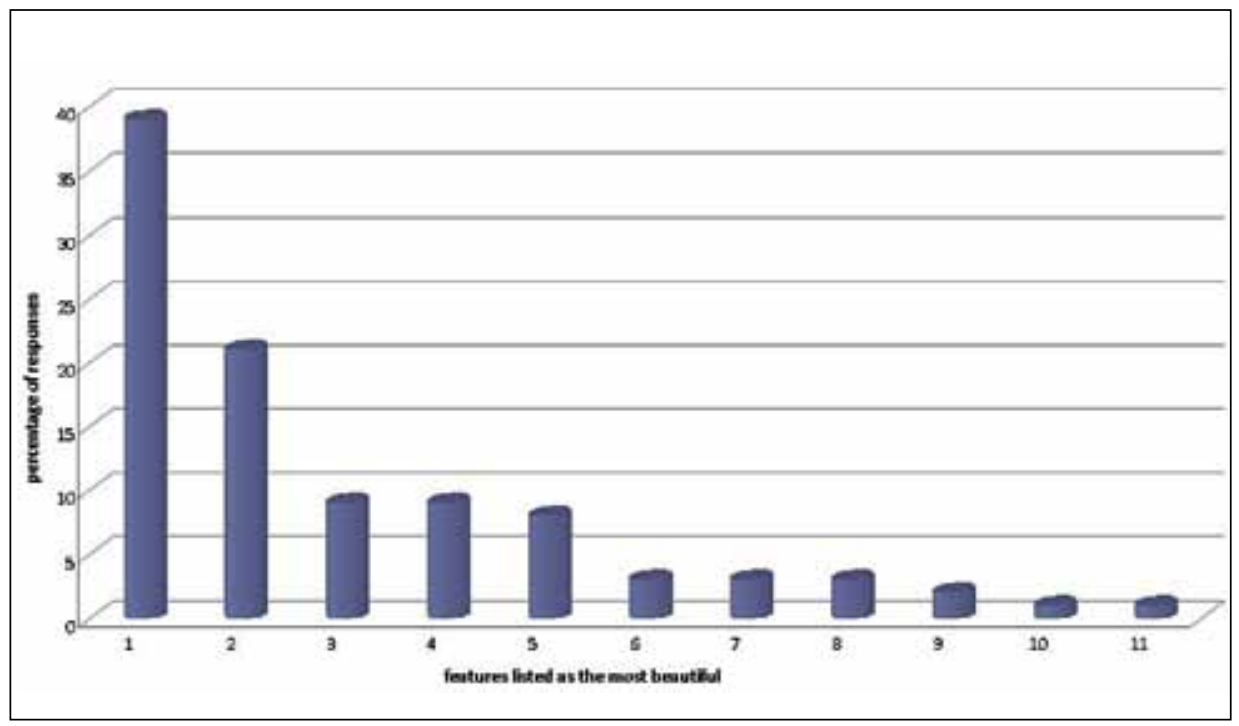

Fig. 1 The most beautiful features of Karlovac

1 - parks, 2 - rivers in general, 3 - Dubovac Old City, 4 - Zvijezda (historic centre), 5 - nature/greenery, 6 - River Kupa, 7 - promenades, 8 - swimming places, 9 - one's own neighbourhood, 10 - River Korana, 11 - favourite café.

Sl. 1. Najljepša mjesta Karlovca

1 - parkovi, 2 - rijeke općenito, 3 - Stari grad Dubovac, 4-Zvijezda, 5-priroda/zelenilo, 6-Kupa, 7 - šetališta, 8 - kupališta, 9 -vlastita četvrt, 10-Korana, 11 - omiljeni kafić.

For Karlovac adolescents, the most important part of urban public space are obviously parks. Apparently, for teenagers, parks are an important part of the "fourth environment" (van Vliet, 1983) - consisting of places beyond their homes, schools and "programmed" recreation and entertainment localities. Teenagers consider parks the most beautiful part of Karlovac and visit them frequently. Parks answer the needs of teenagers in many ways. They offer teenagers a sense of spatial autonomy, they provide them with an opportunity to stay away from adult control and surveillance and to gain experiences in their own social structure. The most frequented parks with large areas are located in the central parts of Karlovac that contribute to a feeling of safety and freedom of movement. Most of the teenagers visit Karlovac parks at least once a week, usually with friends. "Hanging out" (i.e. wandering, talking, making fun) was the most frequent reported activity.

I like to watch what people are doing, how they are dressed, make comments; that is something I can do every day, it clears my thoughts after school (female participant of the focus group on hanging out in the park).

Some respondents, both male and female, also mentioned drinking alcohol.

... our parents already know that we get intoxicated in parks; for somebody it is easier that way, some relax, and some also over do it. 


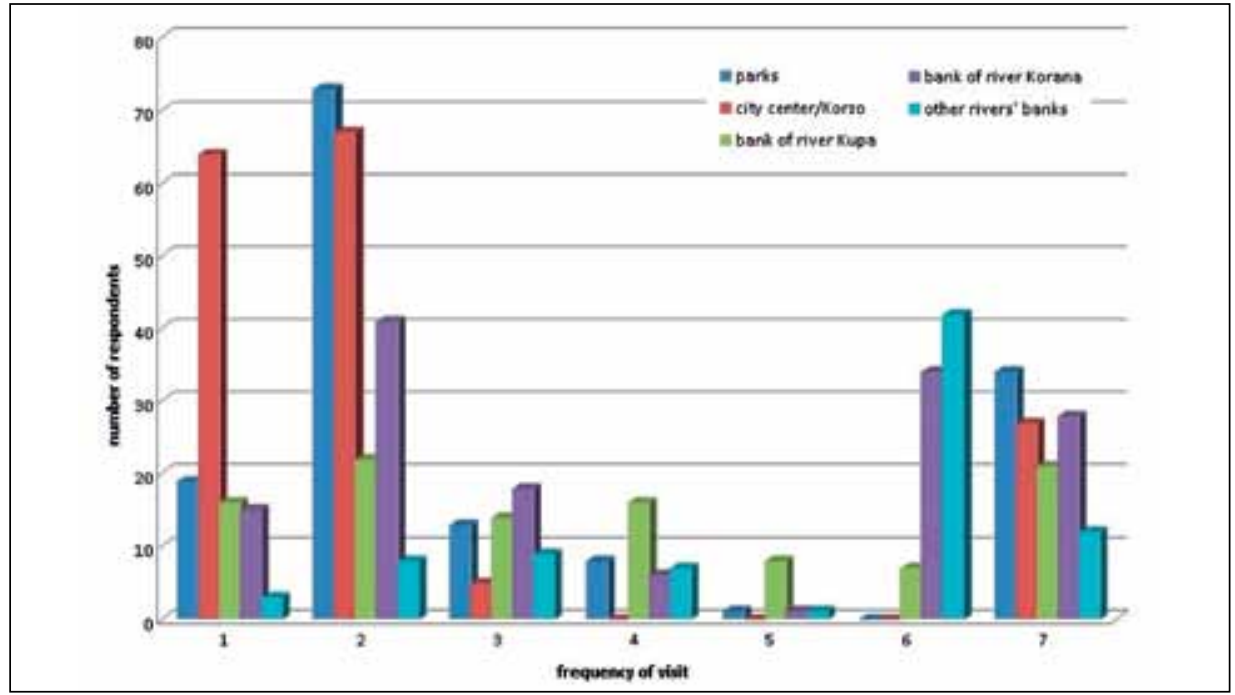

Fig. 2 Frequency of visits to different places in Karlovac

1 - every day, 2 - less than every day, more than once in a week, 3 - less than weekly, more than once in a month, 4 - less frequently, 5 - never, 6 - depending on the season, 7 - other

Sl. 2. Učestalost posjećivanja različitih mjesta u Karlovcu

1 - svaki dan, 2 - rjeđe nego svaki dan, češće nego jednom tjedno, 3 - rjeđe nego tjedno, češće nego jednom mjesečno, 4-rjeđe, 5 - nikada, 6 - ovisno o sezoni, 7 - ostalo

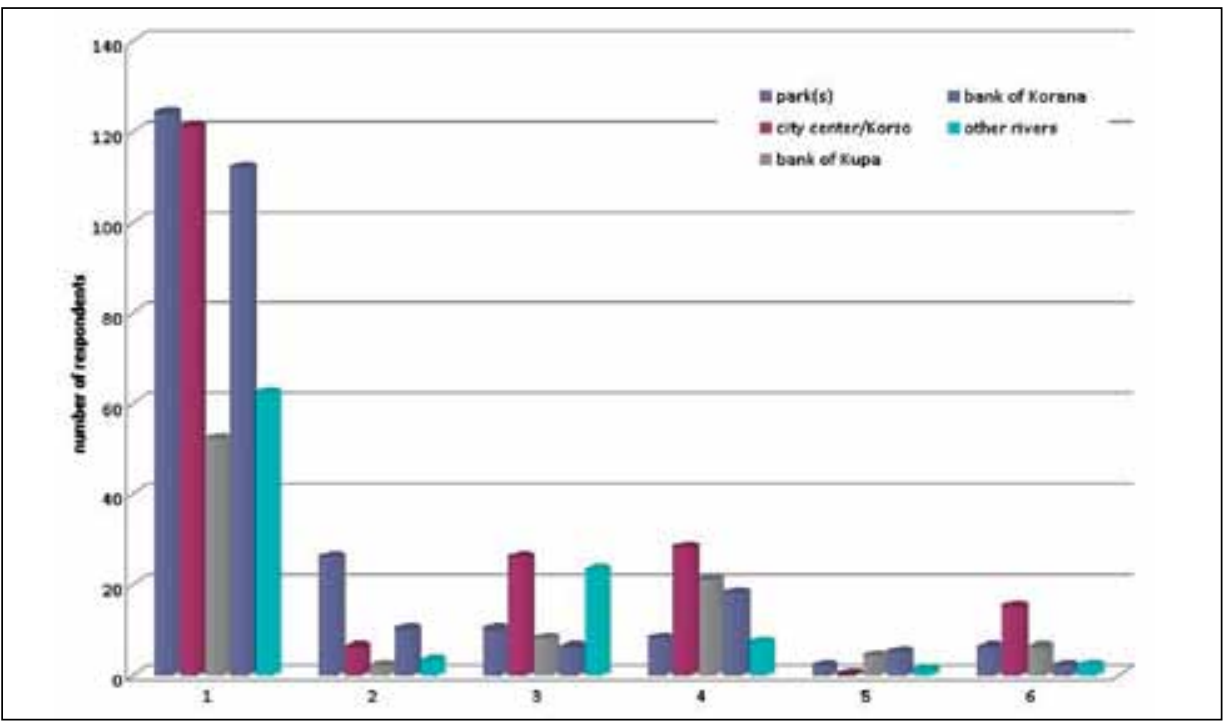

Fig. 3 With whom are the most frequently visited places visited?

1 - with friend(s), 2 - with boyfriend/girlfriend, 3 - with parents/relatives, 4 - alone, 5 - with a dog, 6 - other

Sl. 3. S kime se odlazi na najčešće posjećivana mjesta?

1-s prijateljem (prijateljima), 2-s dečkom/curom, 3-s roditeljima/rodbinom, 4-sam(a), 5-sa psom, 6 - ostalo 


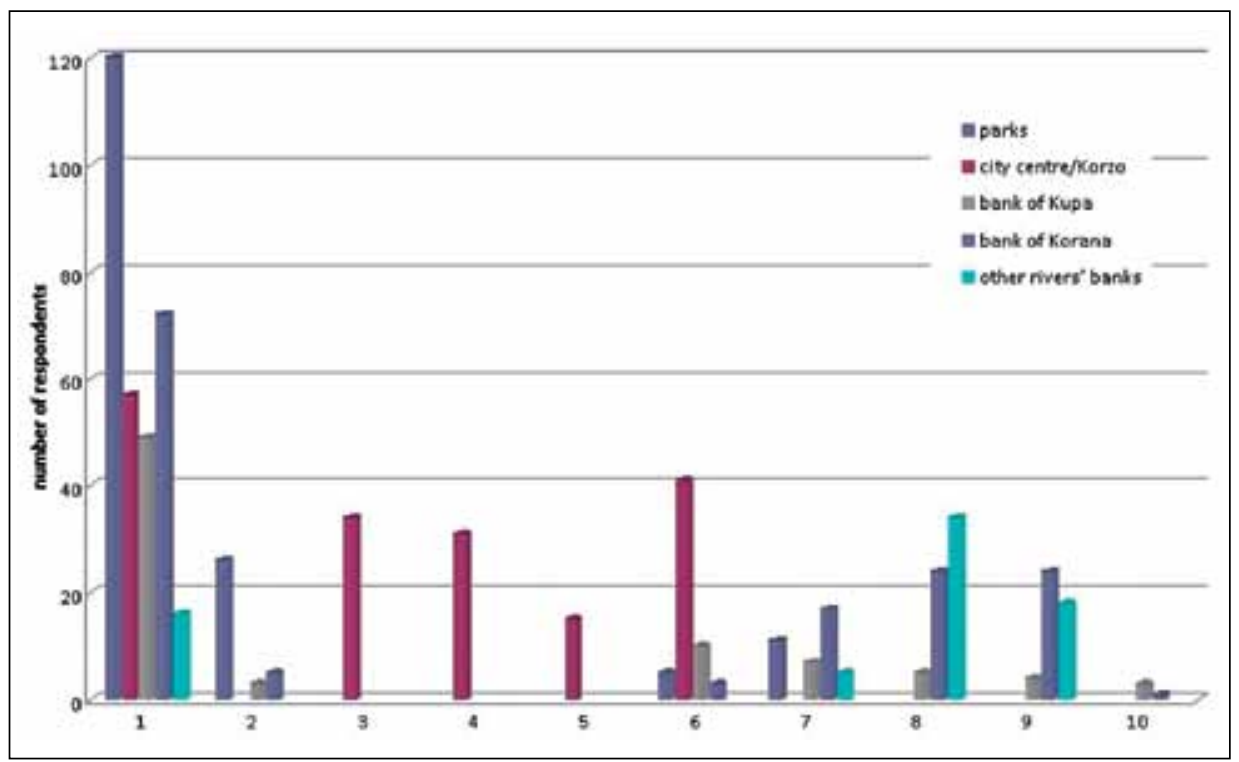

Fig. 4 Usual activities in frequently visited places

1 - hanging out - wandering, talking, having fun, 2 - drinking alcohol, 3 - window shopping, 4 - cafés, coffee, 5 - walking, shops, cafés, 6 - passing through, 7 - sports, recreation, 8 - swimming, 9 - swimming, keeping company, 10 - walking with a dog

Sl. 4. Aktivnosti u najčešće posjećivanim mjestima

1 -šetnja, ,zezanje”, razgovor, 2 - konzumacija alkoholnih pića, 3 - razgledavanje dućana, 4-kafići, kava, 5-šetnja, dućani, kafići, 6-u prolazu, 7-sport, rekreacija, 8-kupanje, 9-kupanje i druženje, 10 - šetnja sa psom

The importance of parks in the daily lives of Karlovac youth is reflected in their attitude to private spaces. Most of cafés which they often visit when they go out ("Papa's Bar", "Cohiba", "Buddha Bar") are located along the very edges of parks. It seems that the usual routine is that after spending their limited money in the café, they just continue their social interaction for free in the nearby park.

There are also other public spaces where teenagers socialise and share experiences. According to our study the banks of Karlovac's rivers, especially the Korana and Kupa, are also very important parts of teens' everyday environments.

We socialise there, have fun, there is always something new, every day something new (male participant in the focus group on hanging out along the Korana).

We take walks along the Kupa, and sit down on benches and watch the water (female participant in the focus group).

Along the river banks, without doubt, it is much more difficult than in the parks to remain within one's own social structure. River banks are utilised by teenagers in diverse ways. Although they are primarily places for social interaction, they are at the same time places for recreation and bathing, places for withdrawal into solitude, sometimes on a 
bicycle or while walking a dog. On the more distant banks of the Mrežnica River, summer family excursions take place, associated with bathing and camping.

Environmental improvements and the introduction of new infrastructure may, paradoxically, threaten the autonomy of young people, and avert them from such spaces. This is confirmed by complaints made by teenagers of the following type:

Since they added sport programmes, Foginovo (the organised bathing place along the Korana) teems with people.

\section{I rarely bath at Foginovo, it's too crowded, too many old folks and kids.}

The commercial area is the next most important landmark in the teenagers' everyday environment. Since teenagers in Karlovac do not have the opportunity to enjoy "the magic of the mall", they make use of the main commercial streets (Korzo, Radic Street) as venues in which to wander around with friends, examine shops, and drink coffee. Commercial areas, as well as parks and river banks, answer the needs of teenagers to be with age-mates in an unsuppressed yet safe place. These are areas where they "come into contact with another groups and show-off their latest clothes and hairstyles, and wait for things to happen" (Matthews, Limb and Percy-Smith , 1998, 195)

Another type of areas where teenagers like to spend time are unprogrammed "places in-between" in neighbourhoods, where teenagers go "to beer halls", go bathing (if a river is nearby), and gather with others.

...it's like some park, well-arranged, and it also has benches... (male participants in the focus group on the area where the neighbourhood squad likes to gather).

Limited access of teenagers to money makes all these open public spaces one of the few affordable solutions for entertainment in their own social structure and a very important available resource for gaining experiences. Actually, there is also no choice - a female participant in the focus group commented, in regard to hanging out in parks.

So, what makes the place favourable in the perspective of older teenagers? We can conclude (see also Chawla, 2002 and Travlou, 2003) that favorite places usually are:

- age-mate gathering places,

- places where teenagers have a feeling of social integration and acceptance,

- places that offer a general sense of safety and freedom of movement,

- settings of varied activity.

\section{UNCOMFORTABLE AND SCARY PLACES}

The next question - which inevitably calls for an answer when dealing with teenagers' everyday environments - concerns uncomfortable and scary places.

At the top of the list of the ugliest features of the town respondents placed ruins, and gloomy and dilapidated buildings. As a town that found itself along the front line during the Homeland War - Karlovac was for several months devastated by artillery fire in 1991 and 1992. Exposed to mortar projectiles and aircraft bombs, the town suffered great damage, which is still clearly manifest today (destroyed buildings, damaged façades). 
The generations of our respondents were born towards the end of war, and grew up in a landscape marked by war-time devastation. The present generation of teenagers, as very strong consumers of public spaces, display a pronounced resistance to parts of the town that still bear traces of the war and post-war neglect.

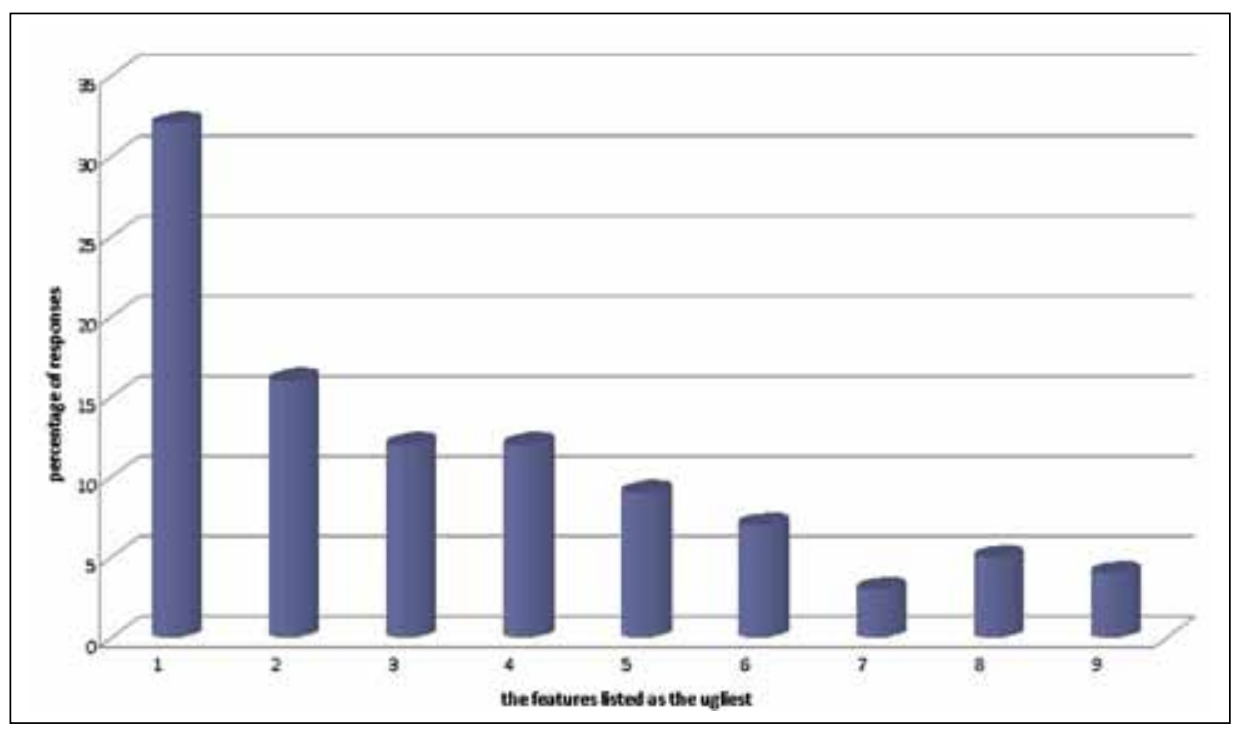

Fig. 5 The ugliest features of Karlovac

1 - ruins, gloomy and dilapidated buildings, 2 - ruined Hotel Korana, 3 - Banija Quarter, 4 - Gaza Quarter, 5 - garbage, 6 - dirty rivers, 7 - Ilovac (location of garbage dump), 8 - nothing/I don't know, 9 - other

Sl. 5. Najružnija obilježja Karlovca

1 -ruševine, tmurne, nesređene zgrade, 2 - porušeni hotel, 3 - četvrt Banija, 4-četvrt Gaza, 5-smeće, 6 - prljave rijeke, 7 - Ilovac (lokacija odlagališta smeća), 8 - ništa/ne znam, 9 - ostalo

"Hotel Korana" was most often mentioned in this context. This hotel destroyed in the war could be considered as the synecdoche of teenagers' attitude to devastated parts of urban landscapes. The hotel, which today's teenagers see as the scorn of the town, was a central gathering place for their parents, with regular dance nights, celebrations and weddings. Now in the evening, according to the respondents' statements, the ruined building is the meeting place of strange people, bad company, drug addicts. It seems that the destroyed hotel has gradually acquired a symbolic meaning - it has become a sign of degradation of the possibilities that the town offers to young people.

When you consider a bit, our parents had more space for going out into the town than we have, more places for entertainment.

They (parents) gathered in old Korana (hotel "Korana"), as we do today in the parks... they went to dances... and now they are mad at us because we go to parks...

As the most unpleasant parts of town, or places which are to be avoided, the Banija and Gaza city quarters are most often mentioned. 


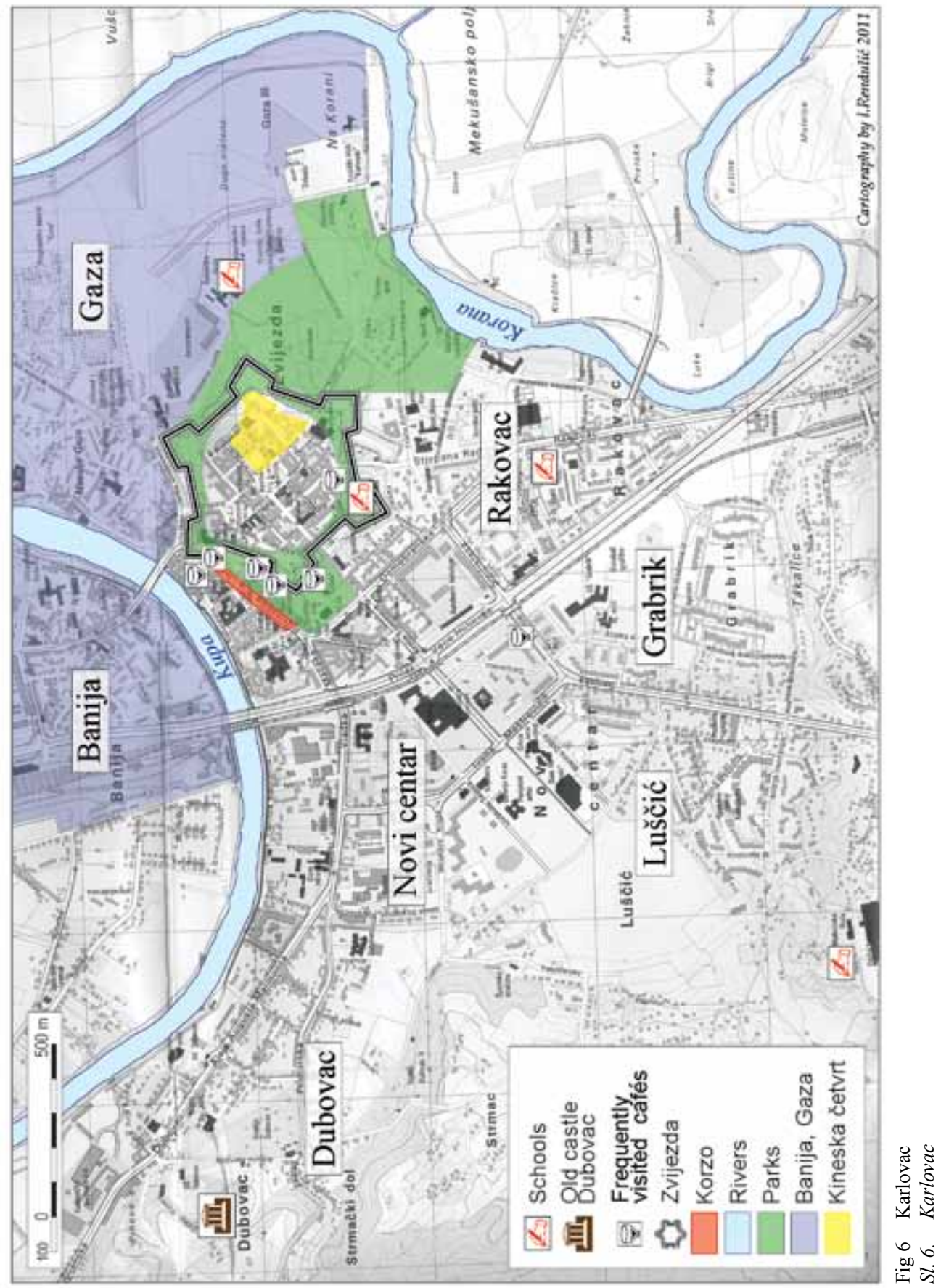


As a part of the former Military Frontier, Karlovac was linked with area of Croatia directly under the Ban's [Viceroy or governor] authority (Banska Hrvatska) through a settlement which received the name Banija specifically due to its location and connecting function. The urban development of Banija was determined to a great extent by the fact that communication between Karlovac and Zagreb went through it. The very heavily travelled road to Zagreb is still the main street of Banija today. Incorporated into Karlovac at the beginning of the 20th century, Banija is a city quarter located only one kilometre from the town's centre. In the 20th century, a favourable traffic/communication position and extensive unused surfaces encouraged the construction of industrial complexes in this quarter, so that Banija received the status of Karlovac's industrial area. The location of industry, together with increased traffic along Banija's main street, obviously formed an attitude about the Banija as being an uncomfortable and disorganised part of the town. This was accentuated in 1978 by the opening of the Ilovac garbage dump in the northern part of Banija. Banija is most often described as disorganised and noisy, but also as an insecure and dangerous area. Poor or non-existent street lighting in certain parts of Banija in the evening hours, and the absence of pedestrian pavements contribute to the fact that adolescents feel insecure in this neighbourhood. Due to the lack of public transportation between certain parts of Karlovac, young people must walk a lot through the town. In conditions with no pavements and poor (or nonexistent) lighting, coming home in the evening becomes a risky endeavour:

In Ilovac, after passing through Banija, the pavement stops, and there are no lights either, and everyone rushes around, so I am not allowed to go into town by foot.

I would go everywhere on foot, if there were pavements.

It is certainly important to note that the absence of pedestrian pavements is not only a problem of Banija. Thus inhabitants of another part of Karlovac, Jelsa, mention the same deficiency:

When they receive their drivers'licenses, young people drive fast, and they caused an accident in front of our house. So my mother lets me out on foot only when it is not dark.

Experiencing Banija as an insecure city quarter is to some extent accentuated by its association with specific groups of people from Banija, for example with the dangerous and violent older gang, and with young problematic people, which is the way in which respondents referred to the protégés of the Children's and Youth Education Home (the "Reform School"), located at the very entrance to this city quarter (from the direction of the town centre). A smart person will not be in Banija, or in Gaza-commented one of the respondents.

Another quarter that teenagers avoid is Gaza. A very short explanation is usually given - the people. A refugee settlement was built in Gaza during the war - at the end of 1992. In this town quarter, located only one kilometre from the centre of Karlovac, 250 prefabricated houses were erected. In 1993, over 5,000 refugees were accommodated in these small houses (Laić, 2007), mostly from the nearby area of Slunj. The refugee settlement was officially closed in 2007 , yet activities on cleaning out its marginal parts continued even in 2009. Thus, Gaza was associated with a refugee settlement for more 
than 15 years and with a newly arrived population from rural areas that had difficulties in orienting itself and was not easily accepted in the urban milieu. The number of refugees gradually diminished, and in their place, legally or illegally, groups of Roma moved in. In the year 2001, a private centre was opened at the edge of the refugee settlement for the accommodation of people with permanent mental, psychological and physical illnesses, and in 2008 a shelter for homeless people was opened in the administration building of the former refugee settlement. This concentration and replacement, as many as four times, of marginal social groups turned Gaza into a type of ghetto for allocating "others". In the experiences of young people, Gaza is a dark, unlit part of town, where everything has died out, with unsanitary conditions, full of poor people, a dangerous neighbourhood associated with Roma, continuous problems, crime, alcoholics, drug addicts and strange people. In the eyes of many of the teenagers, this is a neighbourhood in which one cannot freely stroll, either in daytime or at night, passing through it is frightening and ghastly. Whether or not this depicts reality or prejudices, the fact nevertheless remains that the war-time and post-war association of Gaza with "outsiders" transformed it into a space, which signifies limited movement, fear and avoidance for young people.

Summarising research results (see also Lynch and Banerjee, 1976; Travlou, 2003; Schwab and Standler, 2004; Travlou, Owens, Thompson, Maxwell, 2008, Matthews and Limb, 1999, Chawla, 2002), we can conclude that places that teenagers avoid, or which they fear, are associated as a rule with one or a combination of the following characteristics:

- disorderliness, garbage,

- much traffic, noisy,

- dark, isolated,

- spaces associated with groups of "others" - street gangs, ethnic groups, etc.

\section{NEEDS AND PROPOSALS}

How would young people change their environment, if they could do so? In order to address this issue, we included several hypothetical questions in our survey: What would you do if you were in the role of mayor - what would you change, establish, build, eliminate? The respondents' answers, regardless of their diversity, clearly revealed some general needs. First of all, the need for better infrastructure was expressed. Respondents were in favour of upgrading sport infrastructures, most often they mentioned construction of a swimming pool, which the town lacks. A part of the respondents proposed educational or traffic-related projects. Most frequently, however, the need for better cultural infrastructure was expressed. If they would have the power to do so, $65 \%$ of the respondents would build a cinema in their town, a disco club or an undefined type of facility - a place for concerts, for respectable cultural events, a beautifully organised place to go out to. When asked: what is most lacking in Karlovac? $-70 \%$ of the respondents answered very similarly: places to go out to, concerts, and places for entertainment, clubs, and cinemas.

In a town which once had as many as four cinema halls, all the cinemas closed down after privatisation and thus reopening a cinema is the single most often mentioned desirable project. A cinema is often placed within the context of the need for a large complex, full of various content. A place which would be by their measure, which was described as 


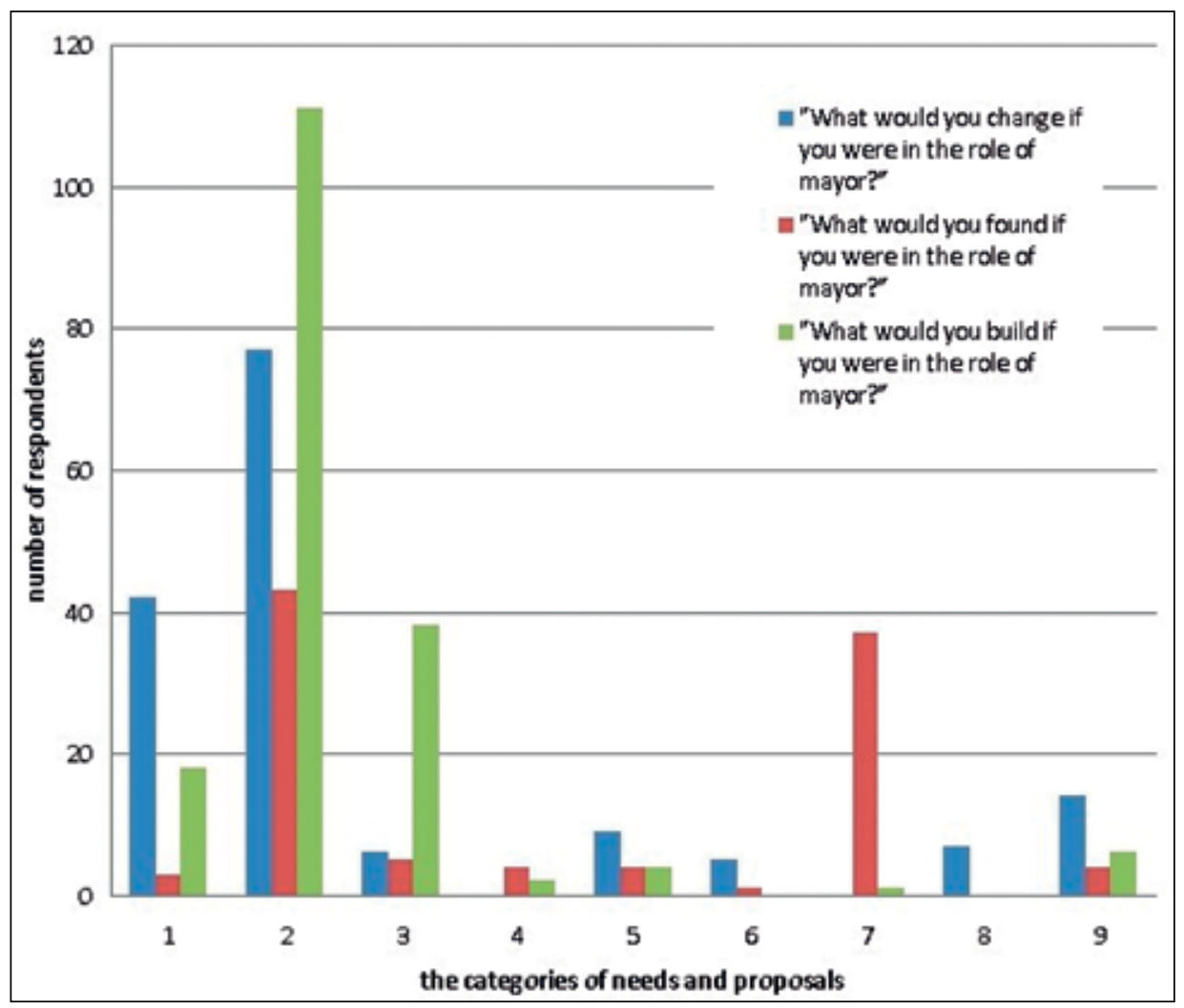

Fig. 7 Older teenagers' needs and proposals

1 - More ordered, clean, adapted landscape, 2 - Better cultural infrastructure for youth, 3 - Better sport infrastructure, 4-Better traffic infrastructure, 5-Better education infrastructure, 6-Safer city, 7 -Better representation of young people in city decision making, 8 - „I would change people”, 9 - Other

Sl. 7. Potrebe i prijedlozi starijih tinejdžera

1 -Uredniji, čistiji, prilagođeniji krajolik, 2 - bolja kulturna infrastruktura za mlade, 3-bolja sportska infrastruktura, 4-bolja prometna infrastruktura, 5-bolja obrazovna infrastruktura, 6-sigurniji grad, 7 - bolje zastupanje mladih u gradskim odlukama, 8- ,promijenio(la) bih ljude”, 9-drugo

beautiful, well-organised, open, secure, clean, well illuminated, and as a setting in which everyone could socialise and all would be together in one place:

... a larger square, and then small benches around it, beside it a park, something like a stage where music is played, then some cinema, so that everything would be close, so that a crowd would gather...

It would be super if there would be a swimming pool, a cinema and a disco in the same place. Symbiosis, everyone would be satisfied!

... and some large hall where [young people] would hang out.

It is interesting to note that very similar ideas among youth, per example in regard to "a teenager hub... with opportunity for all different groups to co-exist... with lots of 
different things to do", can be found in a study by Penny Travlou $(2004,5)$ on the microgeography of teenagers in Edinburgh.

Many respondents (24\%) wish to see Karlovac better organised, cleaner, brighter, more adapted to life - they would restore ruined buildings (and they especially mention renewing the former "Hotel Korana"), they would build pavements and install street lighting where there was none.

Teenagers are obviously aware of the limitations of their own possibilities in the formation of the city environment and infrastructure. A considerable proportion of the respondents (22\%) expressed their desire and readiness for better representation of young people in city decision-making, through the foundation of associations, organisations or youth centres, in which "management would be left to young people under the supervision of older persons". Some respondents even pointed to the existing specific project (Cinema Association of Karlovac - the organiser of the international youth film festival) as a model proving the ability of youth to act independently, to gather age-mated in creative teamwork, and to contribute to a positive change in the town.

\section{CONCLUSIONS}

As our research showed, teenagers in Karlovac perceive their everyday environment in general in a very positive way: the majority of respondents in our sample consider their town to be a safe place, pleasant and full of greenery. However, the following problems surfaced:

- Traces of the war and of post-war neglect are still noticeable, and the generation that grew up surrounded by such a landscape, 15 years after the war, obviously does not want to tolerate it.

- Parks, as the main places were young people spend time, only partially satisfy the basic need of adolescents to gather together with their age-mates, socialise and acquire experience in unsupervised yet safe places; the necessity to upgrade cultural infrastructure is obvious, including the need to build large complexes with different content, which would provide young people with varied activities.

- The insufficiency of street lighting and the absence of pedestrian pavements make parts of the town insecure from the perspective of teenagers.

- Places of fear for young people are most often associated with violent or marginal social groups. The concentration of marginal social groups in one space/area, in the viewpoint of young people, leads to converting it into a city "ghetto". Thus, part of the town is excluded from the zone of free movement.

The precondition for formulating youth friendlier (urban) policies involves gaining an understanding of the everyday environment and the daily routines of movement of young citizens. Incorporating the interests of adolescents into the process of city planning requires:

- research, and not just assumptions in regard to the teenagers' environmental experiences and aspirations; 
- including young people in the formulation of urban policies, at their relative level of competence, through various associations.

Youth strategies in urban policies should proceed from the fact that older adolescents are very intense consumers of public space. Public spaces represent for them an important resource for their development.

\section{REFERENCES}

André, Y. and Bailly, A., 1998: Spatial representations of territories and the world, Prospects 28 (2), pp.279-284.

Bailly, A., MacCabe, C. and Saarinen, T., 1995: Images of the francophone countries and francophone images of the world, Geographica Helvetica 1, pp. 3-11.

Boal, F. W. and Livingstone, D. N. (eds.), 1989: The Behavioural Environment, London, Routledge.

Chawla, L., 2002: Toward better cities for children and youth, in: Growing up in an urbanizing world (ed. Chawla, L.), Earthscan Publications Ltd, London.

Gould, P. and White, R. 1986: Mental maps, Boston, Allen \& Unwin.

Lynch, K. and Banerjee, T., 1976: Growing up un cities, New society 37 (722), 281-284.

Lynch, K., 1977: Growing up in cities: studies of the spatial environment of adolescence in Cracow, Melbourne, Mexico City, Salta, Toluca and Warsaw, MIT Press, Cambridge, MA.

Hester, R. T., 1993: Sacred structures and everyday life: A return to Manteo, North Carolina, in: Dwelling, Seeing, and Designing. Toward a Phenomenological Ecology (ed. Seamon, D.) State University of New York Press, Albany, 271-297.

Horton, J., Kraftl, P. and Tucker, F., 2008: The challenges of 'Children's Geographies': a reaffirmation, Children 's Geographies, 6 (4), 335-348.

Karlovački leksikon (ed. Ott, I.), 2008, Školska knjiga, Zagreb.

Kirk, W., (1963): Problems of geography, Geography 48, pp. 357-71.

Lanegran, D. A., (1986): Enhancing and using a sense of place within urban areas: a role for applied cultural geography, Professional Geographer, 38 (3), 224-228.

Laić, S., 2007: Prognaničko naselje Gaza pred zatvaranjem, www. karlovacki-tjednik.hr/index. php? News\&file $=$ article \&sid=839 (12.09.2010).

Mäkinen, K. and Tyrväinen, L., 2008: Teenage experiences of public green spaces in suburban Helsinki, Urban Forestry \& Urban Greening 7, 277-289.

Matthews, H and Limb, M., 1999: Defining an agenda for the geography of children: review and prospect, Progress in Human Geography 23 (1), 61-90.

Matthews, H, Limb, M. and Percy-Smith, B., 1998: Changing worlds: The mictogeographies of young teenagers, Tijdschrift voor Economische en Sociale Geografie 89 (2), 193-202.

Owens, P. E., 1988: Natural landscapes, gathering places and prospect refuges, Children's Environments Quarterly 5, 17-24.

Owens, P. E., 1994: Teen Places in Sunshine, Australia: then and now, Children's Environments 11 (4), 42-54.

Relph, E. 2002: Place, in: Companion Encyclopedia of Geography (ed. Douglas, I., Haggett, R. and Robinson, 
M.), Routlidge, New York, 906-922.

Relph, E., 2008: Senses of place and emerging social and environmental challenges, in: Sense of Place, Health and Quality of Life (ed. Eyles, J. and Williams, A.), Ashgate, Burlington, VT, 31-44.

Roca, Z. and Roca, M. N. O., 2007: Spatial fixes and flows, development and local/global nexus: A contribution to the landscape research agenda, in: European Landscapes and Lifestyles: The Mediterranean and Beyond (eds. Roca, Z., Spek, T., Terkenli, T., Plieninger, T. and Höchtl, F.), Edições Universitárias Lusófonas, Lisbon, 413-432.

Saarinen, T. F., Seamon, D. and Sell, J. L. (eds.), 1984: Environmental perception and behavior, The University of Chicago Department of Geography Research Paper No. 209.

Schwab, E. and Standler, K., 2004: Youth behaviour and young people's demands for public space: teens_openspace. In: Open space: people space. An international conference on inclusive environments. Proceedings. OPENspace: the research centre for inclusive access to outdoor environments, Edinburgh. www.openspace. eca.ac.uk/conference/proceedings/start.htm (2. 09. 2010.)

Travlou, P., 2003: Teenagers and public space: Literature review, OPENspace: the research centre for inclusive access to outdoor environments, Edinburgh. www. openspace.eca.ac.uk/litteenagers.htm (4.09.2010.)

Travlou, P. S., 2004: A teenagers' survivor guide to public spaces in Edinburgh: Mapping teenage microgeographies, in: Open space: people space. An international conference on inclusive environments. Proceedings. OPENspace: the research centre for inclusive access to outdoor environments, Edinburgh. www.openspace. eca.ac.uk/conference/proceedings/start.htm (02.09.2010.)

Travlou, P., Owens, P. E., Thompson C. W. and Maxwell, L., 2008: Place mapping with teenagers: locating their territories and documenting their experience of the public realm, Children's Geographies 6 (3), 309-326.

Tuan, Y.-F., 1974: Topophilia, Englewood Cliffs, NJ, Prentice-Hall.

van Vliet, W.,1983: Exploring the fourth environment: an examination of the home range of city and suburban teenagers, Environment and Behavior 15, 567-588.

Wratten, E., 1994: Bottom-up planning for urban development: the development planning for real pilot project, RRA Notes 21, 83-90.

Zelinsky, W., 1980: North America's vernacular regions, Annals of the Association of American Geographers 70 (1), pp.1-16.

Received (Primljeno): $2011-01-03$

Accepted (Prihvaćeno): $2011-03-16$

Laura Šakaja, PhD, Associate Professor University of Zagreb, Faculty of Science Department of Geography Marulićev trg 19/II, 10000 Zagreb 1sakaja@geog.pmf.hr

Svjetlana Višnić, univ. bacc. geog., MA student, 1st year, GIS and Geography Education

University of Zagreb, Faculty of Science Department of Geography Marulićev trg 19/II, 10000 Zagreb svjetlana.visnic@gmail.com 